\title{
Economic Empowerment of Urban Farmers in Benin Metropolis
}

\author{
Edeoghon, C.O. \\ Department of Agricultural Economics and Extension Services, Faculty of Agriculture, University of Benin, \\ P.M.B. 1154, Nigeria.
}

\begin{abstract}
This study assessed the effect of Urban Agriculture on food security in Benin metropolis, Edo State, Nigeria. The specific objectives of the study were to: examine the socio-economic characteristics of urban farmers and assess the contribution of urban agriculture on farmers' economic empowerment. One hundred and twenty (120) urban farmers were randomly selected from the study area. Data were obtained with a well-structured questionnaire. A good number (62.6\%) of the respondent were males with a mean age of 45 years with an average house hold size of 9 members. Monthly income was about N26, 000 on the average, while the reasons for engaging in urban agriculture include; high cost of living, profitability and household feeding. Highest economic empowerment provided by urban agriculture were: empowerment to acquire household equipment $(M=3.68)$, better education $(M=3.67)$ and better medical services $(M=3.65)$. Major constraints were land acquisition, capital and transportation difficulty. Results also reveal that there is a significant relationship between farmers years of residence $(r=-0.229)$, urban farming experience $(r=$ $0.221)$ and their economic empowerment. The study therefore recommends that a deliberate effort should be made by urban planners to incorporate community gardens into the city that can be leased out to urban farmers who should be recognized and serviced by financial institutions.
\end{abstract}

Keywords: economic empowerment, community gardens, urban farmers and Benin metropolis.

\section{Introduction}

Urban agriculture defined in simple terms is the growing, processing and distribution of food and other products through intensive plant cultivation and animal husbandry in and around cities (Baikey, and Nasr, 2000). UNDP (1996) also referred to urban agriculture as 'an entrepreneurial activity for people from different levels of income'. For the poorest of the poor, it provides good access to food. For the stable poor, it provides a source of income and good quality food at low cost. For the middle-income families, it offers the possibility of savings and a return on their investment in urban property and for small and large scale entrepreneurs, it is a profitable business.

Smit et al, (1996) claims that an estimated 800 million people are engaged in Urban Agriculture worldwide; of these, 200 million are market producers, employing 150 million people full time. Despite limited support and heavy losses, Urban agriculture (UA) is generating produce valued in the tens of millions of US Dollars, year in year out, in major less developed countries ( LDC's) urban centers' (Mougeut, 2000).

Most of the food consumed in cities must be purchased, and poor families can spend as much as $60-80$ $\%$ of their income on food (Tabatabai, 1993 and Maxwell, 1999).

Urbanization is one of the major issues facing mankind today and is in its extent unique in world history. Neither international government bodies nor national or local government are well prepared to deal appropriately with this development but none of them can afford to ignore this phenomenon (Jacobi et al 2000). Resent survey suggests that the focus of poverty is shifting to the urban areas (Haddad et al., 1998), making food insecurity and malnutrition urban as well as rural problems. Growing urban poverty goes hand in hand with growing food insecurity and malnutrition in the urban areas. The following objectives are addressed:

i. examine the socio-economic characteristics of urban farmers in the study area;

ii. identify farmers reasons for engaging in urban agriculture;

iii. assess the economic empowerment of farmers involved in urban agriculture;

iv. Determine production constrains encountered in urban agriculture.

\section{Hypothesis of the Study}

There is no significant relationship between the socio-economic characteristics of urban farmers and the economic empowerment.

\section{Methodology}

This study was carried out in Ikpoba-Okha and Oredo local government areas of the Benin metropolis Edo State, Nigeria. Benin metropolis of Edo State is made up of three major local government areas namely; Oredo, Egor and Ikpoba-Okha local government areas respectively (NPC, 2006). 


\section{Sample Size and Sampling Techniques}

Two of the three local government area in Benin metropolis were selected, four urban wards were selected, thirty (30) farmers were randomly selected per ward making a total of 120 respondents respectively from both local governments.

\section{Instrument of Data Collection}

The data for the study were collected from primary and secondary sources. The primary data were collected with the aid of a structured questionnaire administered to the literate audience and interview method for the illiterate respondents in the study areas. Secondary data were collected from books of population statistics, and other relevant sources such as journal articles and internet.

\section{Socioeconomic Characteristics of Respondents}

\section{Result And Discussions}

The result on Table 1 reveals that a good proportion $(62.5 \%)(75)$ of the respondents were of the age range of 35- 54 years. This result depicts that farmers were in their productive and economic ages which were an advantage to increase production (Ironkwe, 2005). The result also reveals that a good number $(62.6 \%)$ of the respondent were males this agrees with (Jacobi et al, 2000) that by and large men are more prominent in economic production while women are more related to household.

Also a good number $(57.6 \%)$ of the respondents have lived in the urban centers for more than 30 years. This implies that they have acquired much skills and knowledge to enhance their productivity in urban agriculture over time. The result also shows that respondents have an average household size of 9 suggesting that they have more people to cater for, with a good source of farm labour in the study area. Concerning educational qualification of respondent, results show that $75 \%$ of the respondents have secondary education and above. This implies that high proportions (75\%) of the respondents are literate or educated in the study area. This is favourable since education is important in determining farmers ability to understand and manage unfamiliar technology (Doss and Morris, 2001) Also, majority (90.7\%) of the respondents have more than 6 years' experience in Urban Agriculture with a mean years of experience of 15years.. This implies that respondents with more years of experience in urban agriculture are more likely to be productive by the skill and knowledge gotten over the years. About 58.3\% (70) of the respondents are fulltime farmers while $41.7 \%$ (50) are part-time farmers. This result implies that majority of the respondents are solely into farming as the only source of sustenance and as an informal source of employment. Also results from Table 1 shows that majority of the respondents $(88.49 \%)$ fall within the income group of $\$ 40,000$ and above per month with a mean of \#26,000 per month. This result implies the urban farming in a lucrative profession that can economically empower its practitioners.

Table 1: Socioeconomic characteristics of urban farmers

\begin{tabular}{|c|c|c|c|c|}
\hline Socioeconomic Characteristics & & $\begin{array}{l}\text { Frequency } \\
\text { Total }=(120)\end{array}$ & $\begin{array}{l}\text { Percentages } \\
(100 \%)\end{array}$ & Mean \\
\hline Age (Years) & $\begin{array}{l}15-24 \\
22-34 \\
35-44 \\
45-54 \\
55-64 \\
65 \text { and above }\end{array}$ & $\begin{array}{l}3 \\
19 \\
37 \\
38 \\
14 \\
10\end{array}$ & \begin{tabular}{l|l|}
1.7 & \\
15,8 \\
30.8 \\
31.7 \\
11.7 \\
8.3
\end{tabular} & 45 years \\
\hline \multicolumn{5}{|l|}{ Gender } \\
\hline & Male & 75 & 62.5 & \\
\hline & Female & 45 & 37.5 & \\
\hline \multirow[t]{5}{*}{ Years of residence } & 10 and below & 11 & 9.2 & \\
\hline & $11-19$ & 25 & 20.0 & \\
\hline & $20-29$ & 16 & 13.3 & 29years \\
\hline & $30-39$ & 34 & 28.3 & \\
\hline & 40 and above & 34 & 28.3 & \\
\hline \multicolumn{5}{|l|}{ Household size } \\
\hline & 5 and below & 43 & 35.8 & \\
\hline & $6-9$ & 50 & 41.7 & \\
\hline & $10-14$ & 19 & 15.8 & 9 \\
\hline & $15-19$ & 4 & 3.3 & \\
\hline & 20 and above & 4 & 3.3 & \\
\hline \multirow[t]{6}{*}{ Education } & No formal edu & 6 & & \\
\hline & Primary edu & 24 & & \\
\hline & Secondary ed & 32 & & \\
\hline & $\mathrm{TCH} / \mathrm{NCE} / \mathrm{OND}$ & 41 & & \\
\hline & B.Sc & 16 & & \\
\hline & Post graduate & 1 & & \\
\hline Urban Agriculture Experience & & & & \\
\hline
\end{tabular}


Economic Empowerment of Urban Farmers in Benin Metropolis

\begin{tabular}{|l|l|l|l|l|}
\hline & $<5$ & 9 & 7.5 & \\
\hline & $6-10$ & 54 & 45.0 & 15 \\
\hline & $11-15$ & 25 & 20.8 & \\
\hline & $16-20$ & 13 & 10.8 & \\
\hline & $21-25$ & 10 & 8.3 & \\
\hline Farming status & 25 and above & 9 & 7.5 & \\
\hline & Part -time & 50 & 41.7 & \\
\hline Mntly income (A & Full-time & 70 & 58.3 & \\
\hline & & & \\
\hline & $<10,000$ & 2 & 1.7 & \\
\hline & $10,000-19,000$ & 21 & 17.5 & \\
\hline & $20,000-29,000$ & 20 & 16.7 & \\
\hline & $30,000-39,0000$ & 17 & 14.2 & \\
\hline & $40,000-49,000$ & 33 & 27.5 & \\
\hline
\end{tabular}

Source: field survey, 2011

\section{Reasons for Respondents Participation in Urban Agriculture:}

The most common reasons for engaging in urban agriculture include; high cost of living in the cities ((M $=2.57 ; \mathrm{SD}=0.645)$, its profitability $((\mathrm{M}=2.48 ; \mathrm{SD}=0.621)$, to argument household consumption $((\mathrm{M}=2.21$; $\mathrm{SD}=0.593)$ and finally increased food insecurity in households $((\mathrm{M}=2.07 ; \mathrm{SD}=0.658)$. The standard deviation value of $(0.645)$ shows that the disparity from the weighted mean affected the cost of living in the cities. From the forgoing people apparently fall back to urban agriculture because of the high cost of living in the cities. This may be owing to fact that, urban agriculture makes a vital contribution to food, self- reliance of many major cities, also according to Mougeot (1994); self-reliance is not self-sufficiency but can go a long way in reducing the food insecurity of vulnerable groups.

The standard deviation value of (0.658) shows that the disparity from the mean affected the significance of the mean of food security. This is also in agreement with Haddad et al (1998) whose surveys suggest that the focus of poverty is shifting to urban areas making food insecurity and malnutrition urban as well as rural problems, Zakariah et al (1998) is also in agreement. The level of food insecurity has continued to rise steadily since the 1980s. It rose from about 18\% in 1986 to about $41 \%$ in 2004 (Sanusi et al., 2006). People also undertake urban agriculture on an enterprise for its profitability. The standard deviation value of (0.621) shows that the disparity from the mean affected the significance of the mean of profitability of urban agriculture as an important reason for engaging in urban agriculture. This fact is also in agreement with IDRC (1993) that depending on the income group, Self-produced food is found to account for 16 to $18 \%$ of household food consumption and help save 10-37\% of total income among the poor families of Kampala, Dares Salam and Addis Ababa.

Majority engage urban agriculture as a source of income and not because of frustration. This fact is also in concord with Nugent (1999) that in Dares Salaam there is a demand for more than 44,000 jobs each year only to keep the unemployment rate at a similar level as today. Therefore people are forced to enter into informal jobs, like urban agriculture to gain income.

Table 2: Reasons for engaging in urban ugriculture

\begin{tabular}{|l|l|l|}
\hline Reasons & Mean & Standard deviation \\
\hline High cost of living in cities & $2.57^{*}$ & 0.645 \\
Its profitability & $2.48^{*}$ & 0.621 \\
Household consumption & $2.21^{*}$ & 0.593 \\
Food insecurity & $2.07^{*}$ & 0.658 \\
Recreation/hobby & 1.81 & 0.781 \\
Unemployment & 1.68 & 0.852 \\
Retirement of spouse/old age & 148 & 0.686 \\
\hline
\end{tabular}

Source; Field survey, $2011 *$ Important reasons (mean > 2.00)

\section{Contribution of Urban Agriculture to Economic Empowerment}

Results from Table 3 reveal that respondents have been majorly empowered to meet their basic needs both socially and economically. The table shows that respondents have been empowered in all of the following areas namely; Acquisition of household equipment $((\mathrm{M}=3.68 ; \mathrm{SD}=0.926))$, Ability to afford better education for the family $((\mathrm{M}=3.67)$, Ability to meet household clothing requirement $((\mathrm{M}=3.59)$, and financial independence $(\mathrm{M}=3.56)((\mathrm{M}=3.54)$, Prompt payment of household bills $((\mathrm{M}=3.51)$, active participation in social activities $((\mathrm{M}=3.32)$, ability to afford better accommodation $((\mathrm{M}=3.16)$, ease of employing and paying more staff $((\mathrm{M}=3.04)$ respectively. 
The standard deviation value of (0.926) shows that the disparity from the weighted mean affected the significance of the mean of Acquisition of household equipment. This result clearly states that urban agriculture can contribute to the respondents economic empowerment to some degree.

The standard deviation value of (1.015) shows that the disparity from the weighted $(\mathrm{M} \geq 3.00)$ affected the significance of the mean of ability to afford better education for the family. This result clearly suggest that urban agriculture can contribute to the respondents' economic empowerment educationally by the acquisition of some training that will help increase production and income to support their household to a good extent. This indicates that urban agriculture contributes to poverty alleviation both through a reduction in expenditure and through an increase in income. The income earned is usually spent on non-food items such on transport, housing, school fees, health cost and so on.

The standard deviation value of (0.876) shows that the disparity from the weighted $(M \geq 3.00)$ affected the significance of the mean of ability to afford better medical services moderately. This result clearly shows that urban agriculture can contribute to the respondents' economic empowerment medically to some degree.

The standard deviation value of (0.912) shows that the disparity from the weighted $(\mathrm{M} \geq 3.00)$ affected the significance of the mean of Ability to meet household clothing requirement slightly. This result reveals that urban agriculture can contributed to the respondents' economic empowerment to a great proportion by contributing to household need and other family needs. This view is in agreement with Mougeot, (2000) that urban agriculture connects well not only with their house-holding roles, but also increasing with their need for income The standard deviation value of (0.896) shows that the disparity from the weighted $(\mathrm{M} \geq 3.00)$ affected the significance of the mean of financial independence very slightly. This result implies that urban agriculture can contributed to the respondents' economic empowerment financially to a great degree. This view is in agreement with Freeman (1991) estimated the value of Nairobi farmers' 1987 annual (two-season) off-plot crop production alone to be USD 4 million.

This result reveals that urban agriculture can contribute to the respondents' economic empowerment by helping to settle some household bills. This view is also in agreement with Mougeot, (2000) that urban agriculture connects well not only with their house-holding roles, but also increasing with their need for income The result also implies that respondents do not get enough income as they are supposed but are able to substitute household needs moderately. The reason may be because of their numerous household responsibilities. This view is also in agreement with Mougeot, (2000); that urban households that practice farming tend to spend less on food, which has been found to take about 70 percent of poor household's expenditure (Omonona, 2001; Adejobi, 2004).

Table 3 also show that urban agriculture can contribute to the respondents' economic empowerment to be able to afford better accommodation for their families.

Table 3: Contribution of urban agriculture to economic empowerment

\begin{tabular}{|l|l|l|}
\hline Variable & Mean & Standard Deviation \\
\hline Empowerment to acquire household equipment & $3.68^{*}$ & 0.926 \\
Ability to afford better education for the family & $3.67^{*}$ & 1.015 \\
Ability to afford better medical services & $3.65^{*}$ & 0.876 \\
Ability to meet household clothing requirement & $3.59^{*}$ & 0.912 \\
Financial independence & $3.56^{*}$ & 0.896 \\
Prompt payment of household bill e.g. electric bill, water bill & $3.51^{*}$ & 1.045 \\
Increase in income & $3.49^{*}$ & 1.138 \\
Active participation social activities & $3.32^{*}$ & 1.014 \\
Ability to afford better accommodation & $3.16^{*}$ & 1.100 \\
Ease of employing and payment of staff & $3-04^{*}$ & 1.184 \\
\hline
\end{tabular}

Source; Field survey, $2011 *$ Impacted (mean $\geq 3.00)$

\section{Constraints Faced by Urban Agriculture Practitioners}

Result from Table 4 shows the constraints experienced by farmers engaged in urban agriculture. The following were major problems of farmers : mainly lack of capital or credit $((\mathrm{M}=3.72)$, insecure land tenure $(M=3.24)$, high transportation cost $((M=2.94)$, pilfering of produce $((M=2.86)$, pest and diseases $((M=2.79)$, trespassing and public interference $((\mathrm{M}=2.59)$, lack of technical advice i.e. extension services $((\mathrm{M}=2.54)$ and high cost of input $((\mathrm{M}=2.51)$ were also considered as serious constraints.

However, the standard deviation value (0.594) shows that the disparities from the weighted mean $(\mathrm{M}=>2.5)$ did not affect the significance of the mean of lack of capital as a major constraint. This make capital a very serious challenge. The standard deviation value $(0.748)$ shows that the disparities from the weighted mean $(\mathrm{M}=>2.5)$ affected the significance the mean of pilfery of produce as a major constraint. This is in agreement with the thought of Lourenço-Lindell (1996) that claim that Open-space producers are unwilling to contribute to curbing food insecurity through loss of crops, animals, assets, to theft, commonly reported in surveys. Pest and diseases is also a major constraint. This could reduce the Urban Farmer's productivity greatly thereby reducing 
his economic empowerment. Lack of technical advice as a major constraint could be resolved according to Bamire et al., (2007) who stated that education and experience improve the managerial competence of farmers in production and thus increase productivity.

High cost of input as a major challenge affect urban agriculture production capacity leading to deficiencies in food supplies from the cities. This view agrees with DFID, (2002) that the Nigerian 2000 participatory poverty assessment found that access to agricultural inputs was a higher priority for urban poor than it was for rural poor.

The standard deviation value (0.781) of poor market structure was not significant when compared to weighted mean $(\mathrm{M}=>2.5)$ therefore it was not considered as a serious problem. The reason might be because urban farming products have ready market. According to People and Planet (2005), some 800 million city dwellers are involved in urban and peri-urban agriculture on a small or large scale

Table 4: Urban farming constraints

\begin{tabular}{|l|l|l|}
\hline Constrains & Mean & Std. Deviations \\
\hline Lack of capital & $3.72^{*}$ & 0.594 \\
Insecure land tenure & $3.24^{*}$ & 0.917 \\
High transportation cost & $2.94^{*}$ & 0.725 \\
Pilfery of produce & $2.86^{*}$ & 0.748 \\
Pest and diseases & $2.79^{*}$ & 0.819 \\
Trespassing and interference & $2.59^{*}$ & 0.930 \\
Lack of technical advice & $2.54^{*}$ & 0.916 \\
High cost of inputs & $2.51^{*}$ & 0.778 \\
Inconsistent and negative government policies & 2.44 & 0.951 \\
Restriction due to public health & 2.31 & 0.106 \\
Poor market structure & 2.19 & 0.781 \\
Religion beliefs & .1 .62 & 0.781 \\
Insufficient time devoted to it & 1.57 & 0.860 \\
\hline
\end{tabular}

Source; Field survey, $2011 *$ Serious (mean >2.50)

\section{Relationship between Respondent Socio-economic Characteristics and Respondent Economic Empowerment.}

Table 5 shows the correlation result between respondents socio- economic characteristics and there economic empowerment. Table 5 reveals that only 3 variables have significant relationship on respondent economic empowerment namely; years of residence $(r=0.314)$, educational qualification $(r=-0.229)$ and urban farming experience $(\mathrm{r}=0.221)$. However, Years of Residence in the city had a significant relationship with respondents economic empowerment at the $1 \%$ level of significance which has a positive correlation coefficient (0.00) these implies that farmers that have stayed longer in the urban centers are better empowered economically compared to those who have a shorter stay in the urban areas.

The result of the Educational qualification of respondents has a negative correlation figure $(\mathrm{r}=-0.229)$ and is also significant. This implies that less educated people were more involved in urban agriculture in the study area than the educated ones. This may be due to the fact that most educated respondents in the study area are into urban agriculture on part-time basis while more uneducated respondents undertake urban farming as full time occupation, as a means of sustenance as well as food security. This view is in agreement with Nelson, (1996) that that about 200 million urban dwellers now participate in urban farming, providing 800 million people with at least some of their food. Nevertheless this result contradicts the findings of Maxwell, (1993), who said that literate people tend to participate more in urban agriculture since they know its relevance.

Urban farming experience $(\mathrm{r}=0.221)$ of those with more years of experience in urban agriculture are most economically empowered. This is in agreement with Bamire et al., (2007) who stated that experience improves the managerial competence of farmers in production and thus increases productivity. However, Age correlation result is negative $(\mathrm{r}=-0.053)$ and not significant indicating that the younger ones were empowered; hence urban agriculture can be developed as a youth empowerment programme since it can take a lot of youths out of joblessness and crime. Also, concerning Gender correlation result is negative $(\mathrm{r}=-0.056)$ though not significant. This depicts that females can be greatly empowered when they get involved in urban agriculture. Income of respondents has a positive correlation coefficient $(r=0.012)$ and significant at $1 \%$. This indicates that those with higher incomes are more economically empowered since they had more capital to invest in the business. 
Table 5: Relationship between respondents' socio-economic characteristics and economic empowerment

\begin{tabular}{|l|l|l|}
\hline Variable & Correlation Coefficient (r) & Probability level (P) \\
\hline Age & -0.053 & 0.568 \\
Gender & -0.056 & 0.544 \\
Years of residence (years) & $0.314^{*}$ & 0.000 \\
Household size & 0.028 & 0.763 \\
Education & $-0.229^{*}$ & 0.012 \\
Urban Agric. Experience & $0.221^{*}$ & 0.015 \\
Farming status & 0.124 & 0.176 \\
Income (monthly) & 0.012 & 0.894 \\
\hline
\end{tabular}

Source; Field survey, $2011 *$ Correlation is Significant $(\mathrm{P}<0.05$ and $\mathrm{p}<0.01)$

\section{Summary}

\section{Summary, Conclusion And Recommendation}

A high proportion $(62.5 \%)$ of the farmers were $35-54$ years old, a good number $(62.5 \%)$ of the respondents were mostly males, most practitioners engage in urban agriculture because of high cost of living $(\mathrm{M}=2.57)$ and for its profitability $(\mathrm{M}=2.48)$. Enterprises mainly patronized are mainly vegetable production ( $\mathrm{M}$ $=2.32)$ and poultry production $(\mathrm{M}=2.10)$ while the contribution of urban agriculture to economic empowerment of respondent was considered to be fully impacted. Major constrains of urban agriculture practitioners were mainly lack of capital $((\mathrm{M}=3.72)$ and in-secured land tenure $(\mathrm{M}=3.24)$. It was revealed that years of residence $(\mathrm{r}=0.34)$, educational qualification $(\mathrm{r}=-0.229)$ and urban farming experience $(\mathrm{r}=0.221)$ are significant to respondents' economic empowerment.

\section{Conclusion}

The findings of this study has shown that urban agriculture as an enterprise should be highly commended especially in developing economies like Nigeria, basically as a variable intervention strategy for empowering individuals in the informal labour market by creating jobs for the unemployed and youths, attainment of food security etc. Urban agriculture has been discovered to be an enterprise capable of helping urban poor to earn extra income therefore, reducing their reliance on cash income for growing their own food.

\section{Recommendations:}

1) A deliberate effort should be made by urban planners to incorporate community gardens into the city that can be leased out to urban farmers who should be recognized and serviced by financial institutions.

2) Technical advice should be provided by service providers like extension agents.

[1]. Adejobi, A. O: (2004) Rural Poverty, Food Production and Demand in Kebbi State, Nigeria. PhD. Thesis in the Department of Agricultural Economics, University of Ibadan, Nigeria.

[2]. Bailey, M., \& Nasr, J. (2000, Fall 1999/Winter 2000). From brownfields to greenfields: Producing food in North American cities. Community Food Security News, p. 6.

[3]. Bamire, B.S.,Oluwasola, O. and A.J. Adesiyan (2007). Land Use and Socio-Economic Determinants of Technical Efficiency of Rice Farms in Osun State, Nigeria, in : Haruna, U.; Jubril, A.; Mancha, Y. P and Nasir, M. (eds)proceeding of the Nigerian Association of Agriculture Economics (NAAE), pp.27-35.

[4]. Department for International Development: DFID (2002).Poverty profile in Nigeria

[5]. Doss, C. R. and Morris, M. L. (2001). How does gender affect the adoption of agricultural innovation. The case of improve maize technology in Ghana. Journal of international Association of Agricultural Economists. 1(25):2739.

[6]. Freeman D. B. (1991). A city of farmers: informal urban agriculture in the open spaces of Nairobi, Kenya. Montreal: McGillQueen's University Press.

[7]. Haddad, L., M.Ruel, and J. Garrett (1998): Growing urban poverty and under malnutrition and some urban facts of life. International Food Policy Research Institute, Washington.

[8]. Ironkwe, A.G. (2005). Adoption of yam minisett technology by women farmers in Abia State, Nigeria. Unpublished MSc thesis in Department of Rural Sociology and Extension, MOUA, Umudike, Abia State, Nigeria.

[9]. Jacobi. P.,J.Amend and S. Kiango (2000): Urban Agriculture- a case study of Dares Salaam (Tanzania). In: City Harvest- A Reader on Urban Agriculture GTZ, Eschborn.

[10]. Lourenco-Lindel I. (1996). Food for the poor, food for the city: the role of urban agriculture in Bissau. Paper presented at ODA Workshop on The Social and Environmental Implications of Urban Agriculture. University of Zimbabwe, Harare, 30-31 August 1995.

[11]. Maxwell, D (1993) 'The Impact of Urban Farming Kampala in Household Food Security and Nutritional Status, Makerere Institute of Social/Research, Makewrere University.

[12]. Maxwell D. (1999). Urban food security in sub-saharan Africa. In: Koc M, MacRae R, Mougeot LJA \& Welsh J (eds), For hunger-proof cities: sustainable urban food systems (Ottawa: IDRC), pp 26.

[13]. Mougeot L. J.A.(2000). Urban Agriculture: Defination ,Prescence, Potentials and Risks.In: Growing Cities Growing Food .(Eds) Bakker, N.et.al ; CTA, Netherlands.

[14]. National Population Commission: NPC (1991,and 2006)- Federal Republic Of Nigeria $\quad$ Official Gazette; No2, Abuja $2^{\text {nd }}$ February, 2009.

[15]. Nelson T. (1996). Closing the nutrient loop. World Watch (November/December). Nigeria. Pak. J. Nutr., 5: 62-67.North-Central Nigeria. Pak. J. Nutr., 6: 49-58 
[16]. UNDP (1996): Urban Agriculture Food, Jobs and Sustainable Cities. United Nation Development Program, Publication Series for Habitat2, Vo1. UNDP, New York.

[17]. Smit J, Nasr J \&Rattu A. (1996). Urban agriculture: a neglected resource for food, jobs and sustainable cities. New York: UNDO.

[18]. Omonona, B. T.: (2001).Poverty and its correlates Among Rural Farming Household in Kogi State, Nigeria Ph.D Thesis, Department of Agricultural Economics, University of Ibadan, Ibadan, Nigeria

[19]. People and Planet (2005). People, food and agriculture, Peopleandplanet.net,@ people and the planet pp. 2000-2009.

[20]. Sanusi, R. A., C. A. Badejo and B. O. Yusuf (2006) "Measuring household food insecurity in Selected Local Government Areas of Lagos and Ibadan, Nigeria", palc. J. Nutri, Vol. 5, pp.62-67.

[21]. Tabatabai. H. (1993). Poverty and food consumption in urban Zarie. Cornell Food and Nutrition Policy Program Working Paper 46. Ithaca: Cornell Food and Nutrition Policy Program.

[22]. Zakariah S, Lamptey G.M \& Maxwell D., (1998). Urban agriculture in Accra: a descriptive analysis. In: Armar-Klemesu M \& Maxwell D (eds). Urban agriculture in the Greater Accra Metropolitan Area: Report to IDRC. (Legon: MMIMR). 